\title{
Impact of Court Rulings on Health Care Coverage: The Case of HIV/AIDS in Colombia
}

\author{
Ana Cristina González MD MA and Juanita Durán LLB
}

\begin{abstract}
This article addresses an emerging issue in health care systems: the impact of judicial rulings on public policy regarding financing and delivery of health care services, and the attendant tensions, contradictions and questions. In Colombia, HIVIAIDS patients' use of a legal instrument called tutela, or writ of protection, has produced abundant jurisprudence and prompted health authorities to respond with decisions about HIVIAIDS service coverage that do not consider epidemiologic criteria and sustainability, introducing distortions in the health care system with respect to financing, priority-setting and universality.
\end{abstract}

KEYWORDS Health care systems, HIV, AIDS, legislation and jurisprudence, rights, universal coverage, Colombia

\section{INTRODUCTION}

In many countries, the constitution or bill of rights includes legal mechanisms-such as writs of protection or of habeas corpus-to protect rights, establishing constitutional courts to guarantee their application. In protecting fundamental rights, judges' decisions often impact policies or systems established by the State to implement such rights, including the right to health. $[1,2]$

These judicial decisions are normally one of two types: abstract control or concrete control. Abstract control establishes the constitutionality of a law, measure or policy-in this context, concerning the health system. Concrete control decides in a particular case whether the rights of an individual have been violated. In such cases, the aim is to determine whether the action of an agent of the system has violated a fundamental right and therefore violated the Constitution.

All of these elements have been in place in Colombia since 1991, with the adoption of the new Constitution, and all mechanisms to protect the right to health are used. The Constitution includes a legal recourse called acción de tutela (article 86)[3] and a Constitutional Court that can hear both concrete and abstract cases. Tutela, or writ of amparo or protection, is a mechanism for protecting fundamental constitutional rights allowing any citizen at any time to demand immediate court-ordered protection of such rights whenever these allegedly have been violated by any public or private authority's action or failure to act. Such cases are accorded procedural preference and can be argued by individuals or someone acting on their behalf.[3]

Since the current health system was established in 1993 (see box on Colombia's Health System), writs of protection have been used to obtain access to services not included in the Obligatory Health Plan benefits package (POS, the Spanish acronym). Use of these to request protection of the right to health care has increased not only in absolute numbers of writs presented, but also as a percentage of all writs of protection, reaching $36 \%$ in 2005 (Table 1).

\section{Colombia's Health System}

The General System for Social Security in Health (SGSSS, the Spanish acronym) was established in Colombia in 1993, as an insurance system accessible by two routes: contributory and State-subsidized.

In the contributory route, those with the means to pay make monthly contributions to the system through an insurer, the Health Promoting Entity (EPS, the Spanish acronym). These funds are pooled in the Solidarity and Guarantee Fund, which pays the insurer a capitation premium, in return for which the insurer is obliged to guarantee its affiliates the services included in the Obligatory Health Plan benefits package.

A percentage of the funds in the Solidarity and Guarantee Fund are used to support the State-subsidized route, which gives access to a more limited benefits package to those financially unable to contribute to the insurance plan.

The EPS does not provide services directly but contracts them through a network of health care service-providing institutions.

The system is intended to ensure universal access to health care, fulfillment of this goal depending largely on the number of contributing-plan affiliates and on public funds from the State. Financial sustainability relies on balancing the resources thus available with the scope of the obligatory benefits package.

Table 1: Writs of protection for right to health care, Colombia, 1999-2005

\begin{tabular}{|l|r|r|}
\hline Year & Number & \multicolumn{2}{c|}{$\begin{array}{c}\text { Portion of all writs } \\
\text { of protection (\%) }\end{array}$} \\
\hline 1999 & 21,301 & 24.7 \\
\hline 2000 & 24,843 & 18.9 \\
\hline 2001 & 34,319 & 25.8 \\
\hline 2002 & 42,734 & 29.7 \\
\hline 2003 & 51,944 & 34.8 \\
\hline 2004 & 72,033 & 36.4 \\
\hline 2005 & 81,017 & 36.1 \\
\hline
\end{tabular}

Source: Public Defender's Report: Writs of Protection and the Right to Health.

This phenomenon of resolving questions of health care access through the courts rather than the health system has been termed the judicialization[4] of the health care system. Since judicial rulings are an ongoing process, these decisions affect the health system as a whole, generating tensions, contradictions, and questions. 
The aim of this article is to discuss the impact of judicial decisions on the health system and public policies in health. We propose to generate questions and hypotheses for future research into issues such as the definition of health care benefits packages, financial viability of the health system, and universal access to health care services.

\section{JUDICIAL DECISIONS' IMPACT ON HEALTH CARE BENEFITS PACKAGES}

One critical area in which judicial decisions have had an impact in Colombia is in the definition of health care benefits packages, that is, the obligatory services guaranteed by health insurance. This in turn could have a financial impact on the system and affect its ability to attain the stated goal of universality.

Benefits packages are a response to the tension between population health care needs and distribution of scarce resources, as well as a mechanism to promote equitable and universal access to care. The definition of health care priorities and their incorporation into benefits packages follows a logic of epidemiologic analysis, planning, resource distribution, and collective protection. Judicial decisions do not follow the same logic, but do have the power to alter the content of these packages and mandate structural changes for their implementation.

Judicial decisions can determine health care benefits packages in many ways, but three are especially important. The first occurs when the court deems unconstitutional a policy restricting coverage in a service package. The result is a modification of the service package with generalized effects: coverage is extended to all citizens. For example, a 2003 decision ordered health authorities to include zoledronic acid for cancer treatment; consequently the drug became part of the mandatory health plan, with no analysis of the measure's financial implications.[5]

The second is through concrete control mechanisms, when health authorities are ordered to provide a health service to a specific individual because its exclusion violates their fundamental rights. Such precedent allows anyone in the same situation to demand the same service. This is what occurred when decision T-230 (1999) first mandated tests for viral load in a low-income patient with HIVIAIDS: the Constitutional Court has since ruled the same in more than 100 cases.[6]

Thirdly, benefits packages can be determined by "structural litigation" suits, which are characterized by addressing systemic problems of rights violations that cannot be resolved internally by the health care system.[7] The most important case of this type in Colombia is decision T-760 (2008) that analyzed 22 cases and upheld the rights of the plaintiffs in all. Moreover, it ordered regulatory authorities to take measures needed to resolve the structural problems in the health care system that gave rise to such cases.[8] This sort of decision has a different impact on health care benefits packages, in that it does not order specific changes to the package itself, but orders those responsible to make systemic changes.

All three types of judicial rulings have been made regarding HIV/ AIDS care in Colombia-predominantly the second type, decisions on individual cases that have set precedent for hundreds of other cases-generating pressure on the health system and authorities to redefine benefits package contents, resulting in frequent specific changes.

\section{THE COURTS AND THE CASE OF HIV/AIDS IN COLOMBIA}

The General System for Social Security in Health (SGSSS, the Spanish acronym) acts as an insurance system in which affiliates pay a premium in order to be assured the services included in the POS package. SGSSS Resolution 08 (1994) first established HIVIAIDS-related service coverage in the contributory service plan and in 1995,[9] Resolution 23 did the same for the subsidized plan (see box on Colombia's Health System).[10] Specific services were mandated through other regulations: procedures such as diagnostic tests were listed in the POS manual in 1994[11] and medications covered were listed in Resolution 03 the same year, including only some antiretroviral drugs.[12] Among the most important things not covered in the original package were tests for viral load and other antiretrovirals.

Since the SGSSS created these lists of medications and procedures, affiliates with HIVIAIDS have resorted to legal action to access non-POS services, resulting in the latter's inclusion in the package to complement existing coverage.

Taking 1994 coverage as the point of departure, four key phases or milestones can be identified in the process of broadening coverage through the judicial route of appeal for protection of constitutional rights.

(i) There were few early rulings by the Constitutional Court in the area of HIVIAIDS, all clearly oriented to protecting patients' rights, based on the understanding that the right to health is closely linked to the right to life-that is, the effect that protecting or failing to protect health has on survival-and that special protection is due the plaintiffs as vulnerable individuals. In decision T-271 (1995), the Constitutional Court ruled for the first time that denying antiretrovirals because they were not part of the benefits package violated the fundamental rights of a person with HIVI AIDS, ordering the system to provide the drugs. The Court offered this explanation for ruling in favor of the plaintiffs:[13]

“... The Court is aware that the defendant's refusal is based on regulations...prohibiting the provision of medications outside the officially-approved list; and that there are budgetary considerations...nevertheless... [The Court] reaffirms that the duty to protect a patient's health and life takes priority and becomes meaningless if he or she is denied access to the entire treatment prescribed by the physician ..."

(ii) The second milestone in this process was Constitutional Court decision SU-448 (1997).[14] This ruling was the first to address the question of who has responsibility for covering the costs of non-POS services ordered by judges through a writ of protection. Beyond the concrete cases analyzed, the Court established that when a non-covered service was mandated for a person with HIVIAIDS, the State-not the insurer-was responsible for underwriting the costs, fulfilling the 'duty of solidarity' on citizens' behalf. That same year, health authorities made a specific modification to the benefits package for the first time, in order to include new antiretrovirals for treatment of persons with HIVIAIDS. 


\section{Perspective}

(iii) The third phase was characterized by many writs of protection that reiterated previous decisions mandating provision of uninsured services, ordering their reimbursement from the Solidarity and Guarantee Fund (see box). This period was the most prolific in mandating non-POS services for persons with HIVIAIDS and in which there was surely the greatest financial impact on the system. The most frequent problem seen was lack of POS coverage for persons with AIDS requiring viral load testing to determine treatment plans. The issue became even more critical after 2000, when court decisions aroused new and heated debates on the impact of judicially extended protection of specific individual rights on the whole health system and its sustainability. But no new regulations were issued to address the problem.

Among hundreds of decisions, in T-1207 (2001), the Court upheld the rights of three patients to viral load tests denied them by health authorities. One of the magistrates, while supporting the majority decision, appended a minority opinion expressing concern for its broader impact on the health system.[15] He described the fundamental dilemma of the judicialization of health care, recognizing the importance of protecting vulnerable individuals, such as persons with HIVIAIDS, and at the same time understanding that the Court's ruling would introduce an element of unsustainability into the health system, potentially affecting its aim of universal coverage:

"...the great weakness in the Court's jurisprudence on health is that its conception of health as a fundamental right by virtue of its intrinsic link to [the right to life] has meant it has overlooked the relationship between this social right and respect for equality... In effect, the Court has considered that whenever a medical service is necessary to protect life with dignity, the individual can obtain that service through a writ of protection. But the Court has not pondered whether that medical service is universalizable, whether or not it can be offered to all persons in similar circumstances. By not addressing this question, the Court's jurisprudence risks establishing a doctrine that, in the name of equality and social rights, can produce deep inequalities..."

(iv) This period of intense judicial activity led to a fourth phase, beginning in about 2004, in which services for persons with HIV/ AIDS were broadened through several administrative and legislative decisions. These included regulations established by the pertinent ministry (the Ministry of Health became the Ministry of Social Protection in 2003) to add viral load testing and new antiretrovirals to the POS and establishing guidelines for evidencebased clinical management, among other things.

The response of the health system substantially reduced the number of patients resorting to court-mandated service provision through writs of protection; since 2005, there have been only isolated examples of such cases heard by the Constitutional Court.[16,17]

\section{IMPACT ON FINANCING, PRIORITY-SETTING}

\section{AND UNIVERSALITY}

It is clear that judicial decisions have had an important impact on health care for persons with HIVIAIDS in Colombia. On the one hand, rulings enabled individuals to receive services not covered in the (then) existing POS, as in the examples of viral load testing and some antiretroviral drugs. On the other hand, they generated pressure on the health system to change POS content, as can be seen in the coincidence between judicial decisions and later specific additions to coverage.

Reviewing the course of events from the original POS available to persons with HIVIAIDS in 1994 and current coverage, several phenomena emerge:

- There was frequent and systematic use of writs of protection by users to gain access to non-POS services, mainly curative.

- As a result, adjustments to POS benefits were made to add court-ordered services, without contemplating epidemiologic studies or actuarial assessments of the impact on insurance premiums and without explicit thought given to the impact on the health system as a whole, or on the goal of universal coverage.

- Adjustments to benefits were not made within a framework of a comprehensive POS review, but were specific and ad hoc, violating criteria established in Law 100 of 1993 regarding POS updating, stipulating that this be based on population demographics, epidemiologic profile, available technology, and the economic and financial possibilities of the population and the health system.[18]

We pose the following hypotheses and questions concerning the ways in which court decisions may have introduced distortions in three areas: financing, priority-setting, and universality.

Financing The pressure to provide services specific to HIV/ AIDS, gradually adding them to the POS benefits package, may have delayed other processes also requiring substantial investment, such as broadening coverage to reach universality, gradual broadening of package content in general, or equalization of contributory and subsidized packages. The changes were made without benefit of financial impact analyses and without considering their impact on the system overall.

Priority-setting The focus on services for people with HIVIAIDS may have created fragmentation of benefits packages without applying standard planning criteria for setting priorities. This possible distortion relates not just to HIVIAIDS versus other conditions, but also to how HIVIAIDS itself is approached. The judicial origin of the pressure seems to have resulted in an entirely curative focus, without regard for prevention and health promotion. Priority-setting methods emphasizing a more comprehensive approach seem to have been replaced by attention to problems most visible to the judiciary.

Universality Resolution of judicial emergencies may have delayed processes oriented to consolidating universality of access to health care. In fact, a good number of advances toward universality also needed judicial intervention.

In sum, jurisprudence regarding HIVIAIDS has advanced public policy for protecting individuals with HIVIAIDS. However, it appears to have done so in a context of structural stagnation in which fragmented decisions did not necessarily contribute to the adoption of regulations and criteria benefitting the population as a whole-or to the necessary attention to prevention of HIV/ AIDS itself. -1 . 


\section{REFERENCES}

1. Gloppen S. Litigation as a strategy to hold governments accountable for implementing the right to Health. Health Hum Rights. 2008;10(2):21-36.

2. Pautassi L, Abramovich V. El derecho a la salud en los tribunales. Algunos efectos del activismo judicial sobre el sistema de salud en Argentina. Salud Colectiva. 2008 Sep-Dec;4(3):261-82. Spanish.

3. Constitución Política de Colombia. 1991. Spanish.

4. Uprimny Yepes R. [La judicialización de la política en Colombia: casos, potencialidades y riesgos]. Sur - Revista Internacional de Dereitos Humanos. 2007;4(6):52-69. Portuguese.

5. Consejo de Estado, Colombia. Sala de lo Contencioso-Administrativo. Sect. 3. Sentencie (Dec 11, 2003). Spanish.

6. Constitutional Court (CO). Sentencie T-230 (1999). Spanish.

7. Constitutional Court (CO). Sentencie T-760 (2008). Spanish.

8. Garavito CR, Franco DR. Cortes y cambio social. Cómo la Corte Constitucional transformó el desplazamiento forzado en Colombia [Internet] Bogotá: DeJusticia; 2010 May 5 [cited 2011 June 15]. Available from: http://www.dejusticia org/interna.php?id_tipo_publicacion=13\&id publicacion=781. Spanish.

9. Ministry of Public Health (CO). Consejo Nacional de Seguridad Social en Salud. Acuerdo Número 008 de 1994 [Internet]. 1994 [cited 2011 June 15]. Available from: http://www.pos. gov.co/Documents/Archivos/Normatividad_
Regimen_Contributivo/Acuerdo_08_de1994. pdf. Spanish.

10. Ministry of Public Health (CO). Consejo Nacional de Seguridad Social en Salud. Acuerdo 23 [Internet]. Bogotá; 2010 [cited 2011 June 15]. Available from:http://www.pos.gov.co/Documents/ Actualizaciones $\% 20 \mathrm{y} \% 20$ aclaraciones $\% 20 \mathrm{al} \% 20$ POS-S\%20y\%20POS-C\%201994-2010.pdf. Spanish.

11. Ministry of Public Health (CO). Consejo Nacional de Seguridad Social en Salud. Resolución 5261 (1994). "Manual de Actividades, Intervenciones y Procedimientos del Plan Obligatorio de Salud en el Sistema General de Seguridad Social en Salud." Spanish.

12. Comisión de Regulación en Salud. Resolución 03 [Internet]. Bogotá; Ministry of Public Health (CO); 2009 Jul 30 [cited 2011 June 15]. 213 p. Available from: http://www.minproteccionsocial. gov.co/Normatividad/ACUERDO $\% 20003 \% 20$ DE\%202009.pdf? Mobile $=1 \&$ Source $=\% 2 F$ layouts $\% 2 \mathrm{Fmobile} \% 2 \mathrm{Fview}$.aspx $\% 3 \mathrm{FList}$ \%3D8adb560e-ec04-4d7b-ae9a-b3859deafa a2\%26View\%3D45574dae-85f0-45e3-b0145dc41af8f8c2\%26CurrentPage\%3D1. Spanish.

13. Constitutional Court (CO). Sentencie T-271 (1995). Spanish.

14. Constitutional Court (CO). Sentencie SU-448 (1997). Spanish.

15. Constitutional Court (CO). Sentencie T-1207 (2001). Spanish.

16. Constitutional Court (CO). Sentencie T-262 (2005). Spanish.
17. Constitutional Court (CO). Sentencie T-806 (2006). Spanish.

18. Congress of the Republic of Colombia. Law 100 [Internet]. Bogotá; 1993 Dec 23 [cited 2011 June 15]. 90 p. Available from: http://www.colombia.com/ actualidad/images/2008/leyes/ley100.pdf. Spanish.

\section{THE AUTHORS}

Ana Cristina González Vélez (Corresponding author: acgonzalez@adinet.com. uy), physician with a master's degree in social health research. Regional consultant for the UN Population Fund and visiting researcher at State and Society Studies Center, Buenos Aires, Argentina.

Juanita Durán. Lawyer specializing in economic law. Consultant in constitutional law and faculty member in the University of the Andes program in public policy, constitutional law and regulation, Bogotá, Colombia.

Submitted: February 5, 2011

Approved for publication: June 30, 2011

Disclosures: None 